\title{
Stability of physical therapy effects on temporomandibular disorder*
}

\author{
Estabilidade dos efeitos da fisioterapia na disfunção temporomandibular
}

Muriel Priebe ${ }^{1}$, Ana Gabrieli Ferreira Antunes ${ }^{2}$, Eliane Castilhos Rodrigues Corrêa ${ }^{3}$

${ }^{*}$ Received from the Federal University of Santa Maria, Santa Maria, RS, Brazil.

DOI 10.5935/1806-0013.20150002

\section{ABSTRACT}

BACKGROUND AND OBJECTIVES: Physical therapy contributes to mitigate temporomandibular disorder symptoms because, in addition to stimulating proprioception and the production of joint synovial fluid, it improves adhered muscle fibers elasticity. This study aimed at evaluating the stability of therapeutic results in a follow-up period post- physical therapy in temporomandibular disorder patients.

METHODS: Participated in the study 25 individuals of both genders, with temporomandibular disorder diagnosis. After a multimodal physical therapy program during 10 weeks, which included self-care guidance and home exercises, participants were re-evaluated by the Research Diagnostic Criteria for Temporomandibular Disorders and algometry. Results obtained immediately after treatment were compared to results of the evaluation carried out after two months of follow-up.

RESULTS: From 25 participants, with mean age of 31.6 years, $76 \%$ had no temporomandibular disorder diagnosis immediately after treatment and from these, $68 \%$ have maintained this result in the two-month follow-up period. With regard to joint noises, $60 \%$ of participants have remained with no noises and pressure pain threshold values had no statistically significant differences between evaluations.

CONCLUSION: Multimodal physical therapy intervention, combined with self-care guidance and home exercises has produced, in this study, positive and long-lasting effects on temporomandibular disorder symptoms, maintaining results for two months after treatment completion.

Keywords: Facial pain, Musculoskeletal manipulations, Physical therapy, Temporomandibular joint disorders, Therapeutic approaches.

1. Federal University of Santa Maria, Post-Graduation Program on Human Communication Disorders, Santa Maria, RS, Brazil.

2. Federal University of Santa Maria, Course of Physical Therapy and Rehabilitation, Santa Maria, RS, Brazil.

3. Federal University of Santa Maria, Department of Physical Therapy and Rehabilitation, Santa Maria, RS, Brazil.

Submitted in September 25, 2014.

Accepted for publication in February 10, 2015.

Conflict of interests: none - Sponsoring sources: none.

Correspondence to:

Muriel Priebe

Rua Tuiutí, 1155/301B - Centro

97015-190 Santa Maria, RS, Brasil.

E-mail: muri_priebe@hotmail.com

(C) Sociedade Brasileira para o Estudo da Dor

\section{RESUMO}

JUSTIFICATIVA E OBJETIVOS: A fisioterapia contribui para amenizar os sintomas da disfunçấo temporomandibular, pois além de estimular a propriocepção e a produção do líquido sinovial na articulação, melhora a elasticidade das fibras musculares aderidas. O objetivo deste estudo foi avaliar a estabilidade dos resultados terapêuticos em um período de follow-up após a fisioterapia, em pacientes com disfunção temporomandibular.

MÉTODOS: Vinte e cinco indivíduos, de ambos os gêneros, com diagnóstico de disfunção temporomandibular participaram do estudo. Após um programa de fisioterapia multimodal, durante 10 semanas, que incluiu orientaçóes de autocuidado e de exercícios domiciliares, foram reavaliados pelos Critérios Diagnósticos para Pesquisa em Desordens Temporomandibulares e por algometria. Os resultados obtidos logo após o tratamento foram comparados aos resultados da avaliação realizada após 2 meses de follow-up.

RESULTADOS: Dos 25 participantes do estudo, com média de idade de 31,6 anos, 76\% apresentaram ausência de diagnóstico de disfunção temporomandibular logo após o tratamento edestes, $68 \%$ mantiveram esse resultado no follow-up de dois meses. Quanto aos ruídos articulares, $60 \%$ dos participantes permaneceram sem ruídos eos valores de limiar de dor à pressão não apresentaram diferença estatisticamente significativa entre as avaliaçóes.

CONCLUSÁO: A intervenção fisioterapêutica multimodal, combinada à orientação de autocuidado e exercícios domiciliares produziu, neste estudo, efeitos positivos e duradouros nos sintomas de disfunção temporomandibular mantendo os resultados obtidos por dois meses após o término do tratamento.

Descritores: Condutas terapêuticas, Dor facial, Fisioterapia, Manipulações musculoesqueléticas, Transtornos da articulação temporomandibular.

\section{INTRODUCTION}

Temporomandibular disorder (TMD) is characterized by functional or pathological change affecting the temporomandibular joint (TMJ), which may impair masticatory muscles and stomatognathic system. The number of TMD cases is continually increasing, probably due to current psychological stress, based on current etiologic factors, physical and systemic conditions, as well as psychological factors are 
responsible for TMD orientation and maintenance ${ }^{1,2}$.

TMD symptoms include persistent or recurrent pain in masticatory muscles or TMJ, jaw movement limitations or deviations, TMJ noises, joint discomfort and headache. In addition to impairing functionality, these factors considerably impact quality of life (QL) of these individuals ${ }^{3-5}$.

To minimize TMD symptoms, manual therapy aims, by means of manipulation techniques, mobilization and specific exercises, at stimulating proprioception, producing adhered fibers elasticity, stimulating synovial fluid and promoting pain relief. So, when associated to other physical therapy techniques, it is very useful for treatment outcomes ${ }^{6,7}$.

Guided home exercises and postural reeducation during daily life activities may help controlling TMD symptoms ${ }^{8}$. If combined with therapeutic exercises and manual therapy, they may be effective to treat disc displacement patients and those refractory to conventional treatments, ${ }^{9,10}$. It is also worth stressing the effectiveness of the association of cervical therapy and orofacial treatment in patients with cervicogenig headache associated to TMD signs and symptoms ${ }^{11}$. Algometry is a widely used resource to study the effects of physical therapy on pain. It allows an objective measurement of pressure pain sensitivity, with high level of reliability, both to evaluate myofascial diseases and control group individuals ${ }^{12,13}$. In addition, algometry also contributes to infer the importance of the evaluation of other regions of the body of TMD patients, in addition to the craniofacial region $^{14}$.

More than evaluating results after physical therapy intervention, it is important to follow-up the maintenance of its therapeutic effects. So, this study aimed at evaluating therapeutic effects stability of a multimodal physical therapy program, by comparing TMD signs and symptoms, in addition to evaluating pressure pain threshold observed immediately after treatment and after a 2 -month follow-up period.

\section{METHODS}

Participants were referred by the Orofacial Motility Laboratory where they were evaluated and treated with physical therapy for TMD. Participated in the study individuals of both genders, aged from 18 to 65 years and with diagnosis of TMD obtained by the Research Diagnostic Criteria for Temporomandibular Disorders (RDC/TMD). Patients were submitted to 10 weekly sessions lasting 45 minutes. All participants have signed the Free and Informed Consent Term. Data collected from participants' evaluation cards were: results of RDC/TMD evaluation, presence of joint noises, pain in muscle and joint regions, as well as pressure pain threshold in 16 muscles bilaterally evaluated: anterior, medial and posterior temporal, superior, medial and inferior masseter, sternocleidomastoid and superior trapezius.

Pressure algometer - Force Dial Dynamometer FDK/FDN (Wagner Instruments) was used to evaluate pain threshold $^{9,12}$. This tool may help diagnosis, in addition to checking the efficacy of myofascial pain treatments ${ }^{13}$.
Physical therapy program included a combination of therapeutic modalities, with focus on craniocervicomandibular system structures such as: therapeutic ultrasound, myofascial release, manual therapy, stretching and neuromuscular exercises, in addition to self-care and home exercises guidance $^{15}$. This study has followed the application of modalities of the same protocol.

This study has compared evaluation data immediately after treatment to the evaluation of the same variables in the follow-up period, to observe the maintenance of treatment effects. With regard to RDC/TMD diagnoses, 96\% of patients have improved, not presenting any TMD diagnosis for the group without diagnosis, when evaluated immediately after treatment, and just one out of 25 evaluated individuals has maintained the same initial diagnosis.

Shapiro-Wilk test was used to check data normality. Because data were not parametric, Wilcoxon test was used to compare algometry results between both evaluations, considering significant $\mathrm{p}<0.05(95 \%)$.

This study was approved by the institution's Ethics Committee under protocol 0281.0.243.000-08.

\section{RESULTS}

Participated in the study 25 individuals, being 20 females and 5 males, with mean age of $31.6 \pm 12.21$ years and 19 (76\%) with good post-treatment evolution, that is, they had no TMD immediately after treatment. From these, 17 (68\%) have maintained such result in the 2-month follow-up period, according to RDC/TMD evaluation. One patient (4\%) has maintained the diagnosis of disc displacement with reduction, 4 (16\%) who had some group II diagnosis (disc displacement) have evolved to no diagnosis, and $8 \%$ of those who after treatment had no TMD started to present some group I disorders (muscle disorders) (Figure 1), thus totaling 21 patients with no TMD diagnosis in this evaluation.

There has been no significant difference in pressure pain threshold when comparing results immediately after treatment and two months after its completion (Table 1). Joint noises remained absent in $60 \%$ of patients. In $20 \%$ of pa-

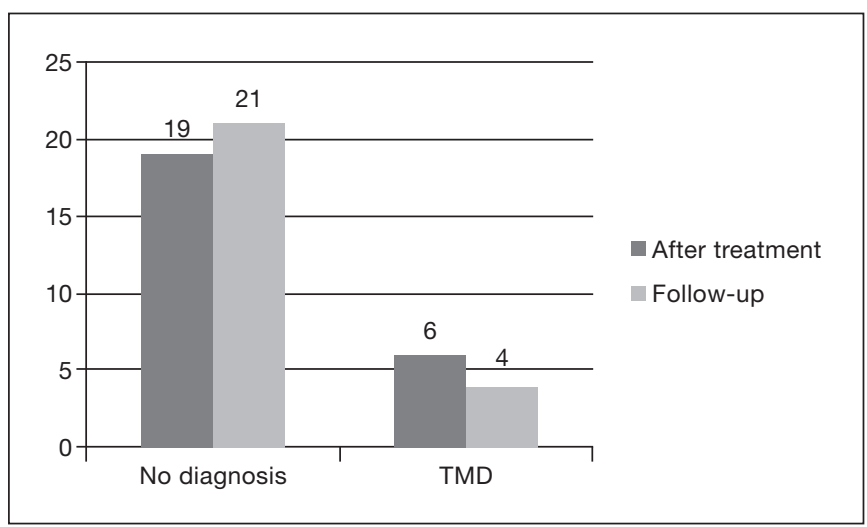

Figure 1. Diagnosis of temporomandibular disorder after treatment and during follow-up 
tients noises they have increased and in remaining patients they have decreased.

Table 1. Pressure pain threshold $\left(\mathrm{kg} / \mathrm{cm}^{2}\right)$ immediately after treatment and follow-up

\begin{tabular}{|c|c|c|c|c|}
\hline Muscles & & $\begin{array}{c}\text { Post- } \\
\text {-treatment } \\
\text { (mean } \pm S D)\end{array}$ & $\begin{array}{l}\text { Follow-up } \\
\text { (mean } \pm S D)\end{array}$ & $\begin{array}{c}\mathrm{p} \\
\text { value }\end{array}$ \\
\hline \multirow[t]{2}{*}{ Posterior temporal } & $\mathrm{R}$ & $4.27 \pm 1.89$ & $4.39 \pm 1.68$ & 0.345 \\
\hline & $\mathrm{L}$ & $4.12 \pm 2.04$ & $4.02 \pm 1.26$ & 0.384 \\
\hline \multirow[t]{2}{*}{ Medial temporal } & $\mathrm{R}$ & $4.33 \pm 1.95$ & $4.12 \pm 1.53$ & 0.728 \\
\hline & $\mathrm{L}$ & $4.00 \pm 1.79$ & $3.93 \pm 1.59$ & 0.782 \\
\hline \multirow[t]{2}{*}{ Anterior temporal } & $\mathrm{R}$ & $3.54 \pm 2.02$ & $3.54 \pm 1.85$ & 0.614 \\
\hline & $\mathrm{L}$ & $3.46 \pm 1.99$ & $3.35 \pm 1.45$ & 0.884 \\
\hline \multirow[t]{2}{*}{ Superior masseter } & $\mathrm{R}$ & $2.39 \pm 1.09$ & $2.15 \pm 0.82$ & 0.190 \\
\hline & $\mathrm{L}$ & $2.43 \pm 1.02$ & $2.15 \pm 0.87$ & 0.666 \\
\hline \multirow[t]{2}{*}{ Medial masseter } & $\mathrm{R}$ & $2.25 \pm 1.09$ & $1.94 \pm 0.86$ & 0.599 \\
\hline & $\mathrm{L}$ & $2.20 \pm 0.98$ & $1.93 \pm 0.91$ & 0.074 \\
\hline \multirow[t]{2}{*}{ Inferior masseter } & $\mathrm{R}$ & $2.26 \pm 1.02$ & $2.04 \pm 0.86$ & 0.283 \\
\hline & $\mathrm{L}$ & $2.05 \pm 0.89$ & $1.95 \pm 0.84$ & 0.496 \\
\hline \multirow[t]{2}{*}{ Sternocleidomastoid } & $\mathrm{R}$ & $1.56 \pm 1.11$ & $1.42 \pm 0.99$ & 0.654 \\
\hline & $\mathrm{L}$ & $1.56 \pm 0.89$ & $1.38 \pm 0.79$ & 0.161 \\
\hline \multirow[t]{2}{*}{ Superior trapezius } & $\mathrm{R}$ & $4.03 \pm 2.35$ & $3.87 \pm 2.19$ & 0.659 \\
\hline & $\mathrm{L}$ & $4.39 \pm 2.62$ & $4.15 \pm 2.28$ & 0.668 \\
\hline
\end{tabular}

$\mathrm{R}=$ righ; $\mathrm{L}=$ left.

With regard to pain at palpation, from 24 structures evaluated by RDC/TMD, 21 have maintained post-treatment results in the follow-up period, except to right inferior masseter, right lateral pterygoid and left temporal tendon.

\section{DISCUSSION}

In the evaluation of TMD diagnosis (RDC/TMD), 19 (76\%) patients had no TMD diagnosis after treatment with a multimodal intervention protocol ${ }^{15}$ and, according to results of this study, 17 (68\%) patients had no TMD at 2 -month follow-up evaluation. In $4(16 \%)$ patients who still had the diagnosis after treatment, there has been disorder remission at 2 -month follow-up evaluation. Through this intervention, authors have achieved a significant decrease in disorder severity, evaluated by the Temporomandibular index ${ }^{15}$, being that such therapeutic effects were maintained after a 2-month follow-up period. Results in line with our study may be attributed, in addition to the multimodal approach, to self-care and home exercises guidance also included in the intervention protocol, critical for the achievement of short and long-term results.

Based on pressure pain threshold results in the follow-up period, there have been no statistically significant changes in any muscle evaluated as compared to values obtained immediately after treatment. A different study, although not presenting statistically significant differences, has shown immediate pressure pain threshold increase of masseter and temporal muscles in patients with latent trigger points, immediately after treatment with manipulation or techniques for soft tissues, without observing the maintenance of such results ${ }^{13}$.

With regard to noises, $60 \%$ have remained without them, $20 \%$ have decreased them and remaining patients had joint noises after 2 -month follow-up. Statistically significant results show the positive effects of cervical manual therapy and of orofacial manual therapy associated to cervical manual therapy on TMD signs and cervical spine disorders ${ }^{11}$. In agreement with our findings, authors have also observed that their results were maintained after a 6-month follow-up period.

Similar to our study, osteopathy and conventional treatment for TMD patients have shown that both were effective to relieve pain, increase maximum mouth opening amplitude and lateral head movement around its axis, being that such effects have remained after a 2-months follow-up period, considering the positive effects in the short and mediumterm. Values of visual analog scale, mouth movement amplitude and head rotation movements got worse for the osteopathy group during the 2-months follow-up period, as compared to re-evaluation immediately after treatment ${ }^{16}$.

A different study with 70 volunteers, has compared one group receiving just self-care guidance with TMD symptoms improvement in $57 \%$ of patients, to a group combining physical therapy (home exercises) and self-care guidance, with 77\% improvement. The group practicing physical therapy and regular self-care has obtained masticatory muscles relaxation, pain relief and improvement in depression symptoms and sleep quality. Authors have indicated that self-care guidance, explanation of risk factors and training in home exercises provide physical and psychological gains, improving symptoms and patients' anxiety ${ }^{17}$.

Some authors have investigated the effects of multimodal interventions on TMD signs and symptoms, which have been maintained even after physical therapy treatment completion, especially when this included passive and active mandibular and cervical exercises, relaxation techniques, postural correction and directed exercises ${ }^{4,11,18}$. With this, it is shown the importance of focusing on the craniocervicalmandibular system for the treatment of TMD patients, involving the spine and cervical muscles, since this system is one functional unit. In addition, this approach introduced in our study, may be an important contributing factor to maintain therapeutic results.

Self-care exercises have proven benefits ${ }^{19}$ and it is considered that, together with patients' education, they are relevant factors to maintain treatment and therapeutic continuity ${ }^{20}$. Also, they are not expensive and perpetuate physical therapy effects, the effect of which has durability, but its decrease is observed after two months ${ }^{15,16}$.

Our study had limitations, such as sample size and lack of investigators' blindness. Also, the scarcity and methodological heterogeneity of studies found on the subject, especially with regard to the maintenance of therapeutic effects, have 
limited our discussion. It is suggested that, to confirm the stability of therapeutic results, longer follow-up periods, above 6 months, should be evaluated.

\section{CONCLUSION}

Most patients have maintained the same results with regard to TMD diagnosis and presence of joint noises after two months of treatment. Treatment effects on pain have also remained, since there has been no difference in pressure pain threshold values evaluated immediately after and two months after treatment completion. So, physical therapy intervention was effective and with long-lasting effects for these patients. This result may be attributed to improved muscle balance and decreased joint overload obtained with the treatment, including the whole craniocervicomandibular system, as well as self-care and home exercises guidance, critical for the achievement and maintenance of therapeutic results.

\section{REFERENCES}

1. Tvrdy P. Methods of imaging in the diagnosis of temporomandibular joint disorders. Biomed Pap Med Fac Univ Palacky Olomouc Czech Repub. 2007;151(1):133-6.

2. Resende CM, Alves AC, Coelho LT, Alchieri JC, Roncalli AG, Barbosa GA. Quality of life and general health in patients with temporomandibular disorders. Braz Oral Res. 2013;27(2):116-21.

3. Dworkin SF, Huggins K, Wilson L, Mancl L, Turner J, Massoth D, et al. A randomized clinical trial using research diagnostic criteria for temporomandibular disorders: axis II to target clinic cases for a tailored self-care TMD program. J Orofac Pain. 2002;16(1):48-63.

4. La Touche R, Fernández-de-las-Peñas C, Fernández-Carnero J, Escalante K, Angulo-Días-Parreño S, Paris-Alemany A, et al. The effects of manual therapy and exercise directed at the cervical spine on pain sensitivity in patients with myofascial temporomandibular disorders. J Oral Rehabil. 2009;36(9):644-52.

5. Strini PJ, Souza GC, Bernardino Junior R, Fernandes Neto AJ. Alteraçóes biomecânicas em pacientes portadores de disfunçáo temporomandibular antes e após o uso de dispositivos oclusais. Rev Odonto. 2009;17(33):42-7.

6. Grossi DB, Chaves TC. Physiotherapeutic treatment for temporomandibular disorders (TMD). Braz J Oral Sci. 2004;3(10):492-7.

7. Kalamir A, Pollard H, Vitello AL, Bonello R. Manual therapy for temporomandibular disorders: a review of literature. J Bodyw Mov Ther. 2007;11(1):84-90.

8. Matta MA, Honorato DC. Uma abordagem fisioterapêutica nas desordens temporomandibulares: estudo restrospectivo. Rev Fisioter Univ São Paulo. 2003;10(2):77-83.

9. Maluf AS, Moreno BG, Alfredo PP, Marques A, Rodrigues G. Exercícios terapêuticos nas desordens temporomandibulares: uma revisão de literatura. Rev Fisioter Pesq. 2008;15(4):408-15.

10. Yoda T, Sakamoto I, Imai H, Honma Y, Shinjo Y, Takano A, et al. A randomized controlled trial of therapeutic exercice for clickink due to disc anterior displacement with reduction in temporomandibular joint. Cranio. 2003;21(1):10-6.

11. von Pierkartz H, Hall T. Orofacial manual therapy improves cervical movement impairment associated with headache and features of temporomandibular dysfunction: a randomized controlled trial. Man Ther. 2013;18(4):345-50.

12. Vedolin GM, Lobato VV, Conti PC, Lauris JR. The impact of stress and anxiety on the pressure pain threshold of myofascial pain patients. J Oral Rehabil. 2009;36(5):313-21.

13. Oliveira-Campelo NM, Rubens-Rebelatto J, Martí N-Vallejo FJ, Albuquerque-Sedí NF, Fernández-de-Las-Peńas C. The immediate effects of atlanto-occipital joint manipulation and suboccipital muscle inhibition technique on active mouth opening and pressure pain sensitivity over latent myofascial trigger points in the masticatory muscles. J Orthop Sports PhysTher. 2010;40(5):310-7.

14. Silveira A, Armijo-Olivo S, Gadotti IC, Magee D. Masticatory and cervical muscle tenderness and pain sensitivity in a remote area in subjects with a temporomandibular disorder and neck disability. J Oral Facial Pain Headache. 2014;28(2):138-46.

15. Freire AB, De Nardi AT, Boufleur J, Chiodelli L, Pasinato F, Corrêa EC. Abordagem fisioterapêutica multimodal: efeitos sobre o diagnóstico e a gravidade da disfunçâo temporomandibular. Fisioter Mov. 2014;27(2):219-27.

16. Cuccia AM, Caradonna C, Annunziata V, Caradonna D. Osteopathic manual therapy versus conventional conservative therapy in the treatment of temporomandibular disorders: a randomized controlled trial. J Bodyw Mov Ther. 2010;14(2):179-84

17. Michellotti A, Steenks MH, Farella M, Parisini F, Cimino R, Martina R. The additional value of a home physical therapy regimen versus patient education only for the treatment of myofascial pain of the jaw muscles: short-term results of a randomized clinical trial. J Orofac Pain. 2004;18(2):114-25.

18. Nicolakis P, Erdogmus B, Kopf A, Nicolakis M, Piehslinger E, Fialka-Moser V. Effectiveness of exercise therapy in patients with myofascial pain dysfunction syndrome. J Oral Rehabil. 2002;29(4):362-8.

19. Michellott A, de Wijer A, Steenks M, Farella M. Home-exercise regimes for the management of non-specific temporomandibular disorders. J Oral Rehabil. 2005;32(11):779-85.

20. Piccoloto MA, Honorato DC. Uma abordagem fisioterapêutica nas desordens temporomandibulares: estudo retrospectivo. Rev Fisiot Univ São Paulo. $2003 ; 10(2): 77-83$. 